\title{
INFLUENCE OF SOME AGRICULTURAL WASTES ON GROWTH, YIELD AND NUTRITIONAL VALUES OF WINTER MUSHROOM (Flammulina velutipes (Curtis) Singer)
}

(Received:12.4.2010)

\author{
By \\ A.H. Khereba, A. M. Farrag, F. R.H. Hassan* and M. Waheed** \\ Vegetable Crops Department, Faculty of Agriculture, Cairo University, Giza, Egypt. \\ * Food Technology Research Institute, Agricultural Research Center, Giza, Egypt. \\ ** Horticulture Department, Ministry of Agriculture, Dokii, Giza, Egypt.
}

\begin{abstract}
The present experiments were carried out during two successive seasons of 2007-2008 and 20082009 at the Mushroom Research Lab., Faculty of Agriculture, Cairo University. A mushroom strain of Flammulina velutipes (Curtis) Singer used in this study was provided by Fujian Agricultural Universiy, China. This study aimed to achieve the following goals:

1- Using some agricultural wastes; i. e., rice straw, wheat straw, Faba bean stalks and maize cobs as well as soft sawdust for the cultivation of a strain of Flammulina velutipes.

2- Determinate the effect of these wastes on growth parameters and yield.

3- Evaluate the produced mushroom fruit bodies for their nutritional value.

Maize cob wastes caused the highest values of total yield first and second flush weight as well as biological efficiency and number of days from spawning till first flush. Meanwhile, rice straw resulted in the lowest first flush percentage weight of clusters and branches. Weight of clusters was the highest when grown in maize cobs. Rice straw caused the lowest values of number and weight of clusters and branches. Flammulina velutipes grown on Faba bean stalks recorded the highest values of crude protein and fibers. Meanwhile, maize cobs resulted in the highest values of total carbohydrates.

It was observed that there were changes in the chemical components of the substrates after cultivation as compared to those before cultivation. Crude protein and ash increased after cultivation. Meanwhile, fibers, fats, and total carbohydrates decreased after the substrate cultivation.
\end{abstract}

Key words: cultivation ,Flammulina velutipes, yield .

\section{1 .INTRODUCTION}

Mushrooms have been treated as a special kind of food, since earliest times. They also have been considered as the oldest microbial food (Kurtzman, 1974). Ancient Egyptians, Chinese and Japanese were probably the first people who professionally cultivated mushrooms (Vangriensven, 1988). Also, Singh (2000) mentioned that, since, a major part of lignocellulosic wastes are burned resulting in multi effect hazards including oxygen deficient in the environment, respiratory diseases and poor visibility at night, cultivation of mushroom on the lignocellulosic wastes is an effective methodology for production of nutritional food and better lignocellulosic waste management. Worldwide production of cultivated mushrooms has been increased at an accelerated rate because they are delicious, nutritious, and have health stimulating properties (Yamanaka, 1997). Nanagulyan (2000) reported that, proposed waste-free technology of growing Flammulina velutipes allows to get a valuable food product as well as some additional feeding materials for livestock. Agricultural and industrial wastes are available in large quantities all over the world, and have a different chemical composition that was studied by many authors in this connection. These wastes are usually suitable for mushroom cultivation as a single or could be adjusted to be suitable by mixing more than one of them or even by addition of some supplements (Hassan, 2002). Venkatroman et al. (1989). reported that, rice straw was found to be a better substrate for the bioconversion by $F$. velutipes than other straw. Royse (1995) stated that sawdust mixed with rice bran could be used as a favorable substrate for $F$. velutipes cultivation. Also, Zhanxi and Zhanhua (2001) mentioned that $F$. velutipes utilizes various kinds of materials such as sawdust, agricultural byproducts(cereal straw, cotton seed residue). Moreover, Hong et al. (2001) cultivated some strains of $F$. velutipes on media consisting of maize straw.Hassan(2002) observed that the mycelium growth rate differed on the rice 
straw, wheat straw, bean stalks,corn cobs and sawdust.. The substrate affected the yield and biological efficiency of $F$. velutipes ( $\mathrm{Lu}$ et al. 1989,Xiong and Jiang, 1999, Zhanxi and Zhanhua, 2001, Pawalk et al., 2001). Variations in the chemical composition of mushroom were affected by substrates (Madbouly, 1987, Madbouly et al., 1993 and Khaled, 1997).

1.1. Moisture content: Crisan and Sands (1978) found that the moisture content of fresh $F$. velutipes was 92\%. Sheng et al., (1997) reported that, the moisture content of 11 strains of $F$. velutipes cultivated in different media (rice straw, wood dust, corn cob and cotton seed husk) ranged from $82-89 \%$.

1.2. Total protein content: Crisan and Sands (1978) found that the protein content of F.velutipes was $25.11 \%$ on dry weight basis. Tonomura, (2001) stated that F.velutipes containted $31.2 \%$ protein (on dry basis). Stamets and Chiltion (1983) recorded that the protein content for F.velutipes fruit bodies grown on different media was $24.5 \%$ on the average (dry weight basis). Sheng et al. (1997) showed that, the protein content was found to be ranged from $8.39 \%-11.8 \%$ (on dry weight basis) according to the cultivation media. The highest protein content was recorded in the fruit bodies grown on rice straw, while the lowest amount was found in those grown on cotton seed husk. Yang et al. (2001) found that F.velutipes contained 20 and $26.7 \%$ crude protein (on the dry basis).

1.3. Crude fiber: Mushrooms contain relatively large amount of crude fiber. Fibers are considered a part of a healthy diet (Oei, 1991) Crisan and Sands (1978) mentioned that, $F$. velutipes fruitbodies contained $3.7 \%$ crude fiber. Whereas Yang et al. (2001) found that crude fiber of $F$. Yang et al. (2001) found that crude fiber of $F$. velutipes was 15 and $16.98 \%$ on dry basis for white and yellow strain, respectively.

1.4. Ash and minerals: Crisan and Sands (1978) mentioned that, $F$. velutipes fruit bodies contained $7.4 \%$ ash (on the dry weight basis) while, a higher amount of ash content being $10.2 \%$ was recorded by Yuexin (1999) for $F$. velutipes mushroom. As for minerals in the fruit bodies of $F$. velutipes mushroom, Crisan and Sands (1978) mentioned that, Calcium, phosphorous, iron, sodium and potassium were presented in this mushroom at 12, 171, 4, 19 and 380 $\mathrm{mg} / 100 \mathrm{~g}$ dry matter, respectively.
In Egypt, enormous quantities of agricultural by- products are produced annually. Rice straw, wheat straw, maize stalks, and other cereal straws, besides sugar cane baggasse are the most local agricultural wastes. The total quantity of the aforementioned agricultural wastes produced in Egypt 2002 reached about 17 million tons. (Agricultural Statistics Report, 2003, Ministry of Agriculture, Egypt ) .

$F$. velutipes mushrooms have been newly obtained from China for their cultivation on local cheap organic wastes. So, the present study aimed to achieve the following goals:

1- Using some agricultural wastes; i.e., rice straw, wheat straw, faba bean stalks and cob maize as well as soft sawdust as industrial waste for cultivation of mushroom strain.

2- Determine the effect of agricultural wastes on the growth parameters and yield of the tested mushrooms.

3- Evaluate the produced mushrooms for its nutritional value.

\section{MATERIALS AND METHODS}

Mushroom strain of Flammulina. velutipes (FC01) was obtained by Fujian Agricultural University, China. The present work was carried out in the Vegetable Crops Department, Mushroom Researches Lab. Faculty of Agriculture, Cairo University, during the two successive seasons 2007- 2008 and 2008- 2009 in $15^{\text {th }}$ November in both seasons.

\subsection{Substrates}

Various agricultural wastes were obtained from the Experimental Farm of the Faculty of Agriculture, Cairo University, as follows:
1- Rice straw
2- Sawdust
3- Faba bean stalks
4-Wheat straw

5- Maize cobs

\subsection{Substrates container}

Plastic bags were also used $25 \times 30 \mathrm{~cm}$. Each contained $1 \mathrm{~kg}$ of wet substrate.

\subsection{Preparation of growing substrate}

Various agricultural wastes were chopped, water was added until its moisture ranged between $60-70 \%$. Wheat bran and limestone were added (5\% for each), sterilized for 45 minutes under 1.5 pressure atmosphere at $121{ }^{\circ} \mathrm{C}$ in the autoclave and cooled to room temperature. (Leong, 1980).

\subsection{Substrate inoculation}

Upon cooling to room temperature $2 \%(\mathrm{w} / \mathrm{w})$ spawn was mixed with the substrate in the containers, each container holds $1 \mathrm{~kg}$ of substrates. The containers were transferred to dark incubation room and left for 30 days. At the end of the incubation period, the bags were opened, the 
substrates were covered by dense mycelium growth.

\subsection{Induction of fruiting bodies}

After completion of the spawn run, the environmental changes to be suitable for inducing fruiting body. The bags were exposed to light by cutting away the top of the bags. The relative humidity was raised to $80-90 \%$.

\subsection{Harvesting}

The mushroom fruiting bodies were harvested up on reaching maturity, at which the fruiting bodies start to "curl up". At this stage, the fruiting bodies were picked up in flushes. Data were recorded on the following characters:

1- Number of days from spawning to the first flush.

2-Weights of fruiting bodies of first flush in $(\mathrm{g})$.

3- Total yield weight of all fruiting bodies picked during the whole period of growth in $(\mathrm{g})$.

4- Percentage of the first flush to total yield was calculated according to the following equation:

Yield of the first flush

Total yield

5- Biological efficiency (BE): was estimated according to the following equation:

Fresh weight of total yield

Weight of dry substrates 100

\subsection{Quality of fruiting bodies: The morphological characters}

The following measurements were recorded on fruiting bodies of the first flush:

1- Average weight of fresh cluster of fruiting bodies in $(\mathrm{g})$.

2- Number of branches in the cluster.

3- Fresh weight of branches of the cluster in (g).

4- Length $(\mathrm{cm})$ and thickness $(\mathrm{mm})$ of the stipes of the branches.

5- Diameter $(\mathrm{cm})$ of capes.

\subsection{Chemical characters}

Samples were taken from full cap and stipes of the fruiting bodies, Mixed together and analyzed. The following measurements were taken:

\subsubsection{Moisture}

The moisture content was determined by keeping the sample in an oven at $105{ }^{\circ} \mathrm{C}$ till constant weight, according to (A. O. A.C. 1980).

\subsubsection{Ash}

The ash was determined according to (A. O. A. C 1980) by heating the sample in a muffle at $550{ }^{\circ} \mathrm{C}$ to constant weight.

\subsubsection{Crude protein}

Crude protein of mushroom was calculated from total nitrogen content as determined by the micro-kjeldahi method (A. O. A. C 1980), using the conversion factor $(\mathrm{N} \times 6.25)$.

\subsubsection{Crude fiber}

Crude fiber content of mushrooms was determined according to the method of Chang and Quimio (1982).

\subsubsection{Crude fat}

Crude fat of mushroom was determined by Soxhlet procedure similar to the basic method described in A.O.A.C (1980) and modified by Chang and Quimio (1982).

\subsubsection{Total carbohydrates}

Total carbohydrates were calculated as follows.

Total carbohydrates $=100-($ Moisture + Ash + Crude protein + Crude fiber+ Crude fat) according to A.O.A.C. method (1980).

\subsubsection{Chemical composition of substrates}

Samples of the substrates were taken before spawning and after harvesting to determine moisture, crude protein, ash, crude fat, crude fiber and total carbohydrates.

\subsubsection{Experimental design}

Randomized complete block design with 3 replicates was adopted.

All data were statistically analyzed according to Gomez and Gomez(1984).

\section{RESULTS AND DISCUSSION}

The data presented in Table (1) indicate the effect of different substrates on the weight of total yield, first flush, second flush, number of days until first flush and the biological efficiency in both seasons. Data showed significant differences between substrates on the total yield, first flush, second flush and biological efficiency on both seasons. The best results on the previous characters were obtained by applying maize cobs followed by faba beans stalks and wheat straw then sawdust. Meanwhile rice straw caused the lowest values. As regarding to the first flush percentage, data showed significant differences between the substrates used to cultivate Flammulina velutipes in both seasons. Using rice straw resulted in the highest values followed by faba bean stalks or wheat straw then sawdust. On the other hand, the lowest values were obtained by applying maize cobs. Results of the present work are in agreement with those obtained by Stamets and Chiltion (1983), Lu et al. (1989), Xiong and Jiang (1999), Oei (1991) and Tonomura (2001). They found that the yield of $F$. velutipes was equivalent to $20-37 \%$ of the initial wet weight of the substrate . Ghada (2004) found that the yield of the first flush represented $51-72 \%$ of the total 
yield of $F$. velutipes. as reported by Flegg (1997) and Hassan (2002). Also, Xiong and Jiang (1999)found that the total yield of $F$. velutipes ranged from 193-213g when grown on different substrates. Tange et al.(2001) reported that rice straw substrate gave the lowest yield.. Zhang et al. (2001) obtained a BE of $112 \%$ when cultivated $F$. velutipes on cotton seed hulls. Meanwhile, Stamets (1993) rrecorded higher BE of $150 \%$ for F. velutipes.

Zou et al. (2005) found that all growth promoting agents markedly accelerated hyphal growth of the fungus and increased its yield. An optimum combination was identified, which shortened vegetative growth period by 4-6 days and increased the biological efficiency by $55.08 \%$. Sharma et al. (2006). indicated that the addition of wheat bran to the sawdust medium enhanced the activity levels of endo-glucanase, exoglucanase, xylanase and laccase, whereas the addition of cotton seed cake and deoiled soybean resulted in decrease activity of these enzymes. Wheat bran and deoiled soybean, at the proportion of $10 \%$ were the best supplements for mycelial growth of $F$. velutipes. The addition of wheat bran to the medium caused an increased biological efficiency and quicker spawn running than in the control medium, whereas poor spawn running and no fruiting-body formation were recorded in the medium enriched with cottonseed cake, soybean meal, or deoiled soybean and found that the incorporation of $10 \%$ wheat bran into sawdust resulted in the most rapid spawn run and the highest biological efficiency (37.5\%).

\subsection{Days from spawning until first flush}

The effect of substrates on the number of days from spawning till the first flush(Table1) was not significant in the first season. In the second season, there were significant differences between the substrates applied to cultivate Flammulina. Sawdust caused the lowest number of days from spawning till the first flush. Flammulina cultivated on maize cobs recorded the highest number of days. The above mentioned results could be attributed to, that maize cobs are richer in nutrients than sawdust, which encourage mycelium growth. Bahl (1994) reported that grain spawn is easier to plant than other materials and the mycelium growth was faster when using grain. On the other hand, saw dust contains many complex compounds such as lignin and resins which altered the growth of mushroom mycelium.The present results are coinciding with those reported by Tonomura (2001). Also, Stamets and Chiltion (1983) recorded that the media consisted of 4 parts of sawdust plus one part of bran gave good results. The same authors' (1983) and Oei (1991), stated that at spawn running temperature of $22-26{ }^{\circ} \mathrm{C}$ and relative humidity of over $90 \%$, the incubation times of $F$. velutipes ranged from 20 to 30 days. Regarding the fruiting bodies development time, these results coincide with those reported by Stamets (1993), who found that fruiting body development for $F$. velutipes took 5-8 days. Tonomura (2001) found that incubated $F$. velutipes bags fruited after 12-14 days. From the present data, it could be concluded that, the type of media had an obvious effect on incubation period of $F$. velutipes and a slight effect on pin heads appearance and fruit bodies developmental time.

\subsection{Quality of first flush}

\subsubsection{Cluster number of first flush}

Data represented in Table (2) indicate that the effects of different substrates on cluster number of first flush were significant in both seasons. The highest numbers of clusters were obtained with the application of wheat straw or faba bean stalks followed by maize cobs then sawdust, meanwhile rice straw resulted in the lowest values.

\subsubsection{Weight of clusters, number and weight of branches}

In both seasons, significant differences were detected in the weight of clusters and the weight of branches (Table 2).

\subsubsection{Cultivation of Flammulina velutipes}

In maize cobs caused the highest values of weight of branches followed by sawdust or faba bean stalks, then wheat straw. Meanwhile rice straw resulted in the lowest values .Sawdust caused the highest values of the number of branches while rice straw caused the lowest values.

\subsection{Stem length}

Data in Table (3) indicate that there were significant differences between substrates on stem length in both seasons. Flammulina mushroom cultivated in maize cob substrates had the tallest stems followed by wheat straw and rice straw without significance between them, then faba bean stalks. Stem length recorded the lowest values when grown in sawdust substrates.

\subsection{Stem thickness}

The effect of different substrates on stem thickness in the first season was not significant, while it was significant in the second season. Stem thickness gave the lowest values when cultivated in maize cobs substrate.

$F$. velutipes mushroom had round small white cap, central over long stem and grown in clusters. Also, the data prove that fruit bodies of $F$. velutipes had pleasant odor. The gills were white, while stems were white and the lower part of the stems turned yellow to brown by age. The cap 
Table (1): Effects of substrates on the total yield (g), first flush (g), \% first flush, second flush (g), BE \% and N. days from spawning till first flush of $F$. velutipes.

\begin{tabular}{|c|c|c|c|c|c|c|}
\hline \multicolumn{7}{|c|}{ First season (2007-2008) } \\
\hline Substrates & T. Yield & First flush & $\begin{array}{c}\text { First flush. } \\
\%\end{array}$ & Second flush & ВE\% & $\begin{array}{c}\text { N. days from spawning } \\
\text { till first flush }\end{array}$ \\
\hline Rice straw & 33.70 & 31.34 & 92.90 & 2.36 & 12.52 & 60.70 \\
\hline $\begin{array}{l}\text { Wheat } \\
\text { straw }\end{array}$ & 100.00 & 78.74 & 78.80 & 21.34 & 31.15 & 60.30 \\
\hline Maize cob & 208.10 & 135.10 & 65.00 & 73.00 & 62.87 & 60.30 \\
\hline $\begin{array}{l}\text { F. bean } \\
\text { stalks }\end{array}$ & 108.30 & 85.90 & 79.40 & 22.47 & 30.92 & 59.70 \\
\hline Sawdust & 78.40 & 57.81 & 73.90 & 20.57 & 30.41 & 59.30 \\
\hline LSD $5 \%$ & 11.13 & 13.44 & 10.67 & 15.23 & 3.18 & N.S. \\
\hline \multicolumn{7}{|c|}{ Second season (2008-2009) } \\
\hline Substrates & T. yield & First flush & $\begin{array}{c}\text { First flush. } \\
\% \\
\end{array}$ & Second flush & BE \% & $\begin{array}{c}\text { N. days from spawning } \\
\text { till first flush }\end{array}$ \\
\hline Rice straw & 31.90 & 29.10 & 91.80 & 2.80 & 12.36 & 60.30 \\
\hline $\begin{array}{l}\text { Wheat } \\
\text { straw }\end{array}$ & 105.10 & 83.26 & 79.29 & 21.84 & 33.28 & 59.60 \\
\hline Maize cob & 212.60 & 149.10 & 70.10 & 63.26 & 64.63 & 61.00 \\
\hline $\begin{array}{l}\text { F. bean } \\
\text { stalks }\end{array}$ & 119.50 & 94.14 & 80.50 & 23.35 & 35.36 & 60.70 \\
\hline Sawdust & 80.30 & 60.88 & 75.60 & 19.42 & 30.02 & 59.00 \\
\hline LSD $5 \%$ & 8.25 & 11.83 & 6.69 & 10.05 & 4.22 & 0.81 \\
\hline
\end{tabular}

Table (2): Effects of substrates on the number of clusters, weight of clusters (g), number of branches and weight of branches (g) of $F$. velutipes.

\begin{tabular}{|c|c|c|c|c|}
\hline \multicolumn{5}{|c|}{ First season (2007-2008) } \\
\hline Substrates & N. clusters & W. clusters & N. branches & W. branches \\
\hline Rice straw & 2.81 & 11.14 & 7.60 & 1.46 \\
\hline Wheat straw & 5.22 & 15.09 & 8.53 & 1.78 \\
\hline Maize cob & 3.93 & 34.54 & 16.59 & 2.08 \\
\hline F. bean stalks & 4.85 & $\mathbf{1 7 . 7 0}$ & $\mathbf{1 0 . 4 8}$ & 1.70 \\
\hline Sawdust & 3.10 & 19.49 & $\mathbf{1 0 . 5 1}$ & 1.85 \\
\hline LSD 5\% & 0.63 & 4.76 & $\mathbf{1 . 5 2}$ & 0.31 \\
\hline \multicolumn{5}{|c|}{ Second season (2008-2009) } \\
\hline Substrates & N. clusters & W. clusters & N. branches & W. branches \\
\hline Rice straw & 2.58 & 11.30 & 7.58 & $\mathbf{1 . 5 0}$ \\
\hline Wheat straw & 5.44 & 15.35 & 8.60 & 1.80 \\
\hline Maize cob & 3.80 & 38.75 & $\mathbf{1 0 . 4 5}$ & 2.20 \\
\hline F. bean stalks & 5.20 & 18.49 & 10.75 & 1.80 \\
\hline Sawdust & 2.90 & 20.31 & 17.64 & 1.94 \\
\hline LSD $5 \%$ & 0.52 & 3.42 & 1.07 & 0.40 \\
\hline
\end{tabular}

Table (3): Effects of substrates on stem length $(\mathrm{cm})$, cap diameter $(\mathrm{cm})$, stem thickness $(\mathrm{cm})$ of $F$. velutipes.

\begin{tabular}{|c|c|c|c|}
\hline \multicolumn{4}{|c|}{ First season (2007-2008) } \\
\hline Substrates & Stem length $(\mathrm{cm})$ & Cap diameter $(\mathrm{cm})$ & Stem thichness (cm) \\
\hline Rice straw & 11.00 & 2.09 & 0.32 \\
\hline Wheat straw & 11.20 & 2.20 & $\mathbf{0 . 3 0}$ \\
\hline Maize cob & 12.00 & 2.19 & 0.26 \\
\hline F. bean stalks & 10.80 & 1.95 & 0.30 \\
\hline Sawdust & 9.40 & 1.73 & 0.32 \\
\hline LSD 5\% & 1.08 & N.S. & N. S. \\
\hline \multicolumn{4}{|c|}{ Second season $(2008-2009)$} \\
\hline Substrates & Stem length $(\mathrm{cm})$ & Cap diameter $(\mathrm{cm})$ & Stem thickness $(\mathrm{cm})$ \\
\hline Rice straw & 11.10 & 2.01 & 0.31 \\
\hline Wheat straw & 11.10 & 2.27 & 0.31 \\
\hline Maize cobs & 11.80 & 2.18 & 0.25 \\
\hline F. bean stalks & 1.70 & 1.97 & $\mathbf{0 . 2 9}$ \\
\hline Sawdust & 9.10 & 1.96 & $\mathbf{0 . 3 0}$ \\
\hline LSD $5 \%$ & 0.58 & N. S. & 0.03 \\
\hline
\end{tabular}


diameter ranged from 1.7 to $2.3 \mathrm{~cm}$. This result is within the range of the results obtained by Stamets (1993) ,1-5 cm ,Zhanxi and Zhanhua (2001), 0.8$1.5 \mathrm{~cm}$ and Tonomura (2001), $2-3 \mathrm{~cm}$. Moreover, the results in the same Table (3) reveal that branches of fruit body weight ranged from 1.5 to $2.2(\mathrm{~g})$. Also, stem length ranged between 10.5and $19 \mathrm{~cm}$ and $0.2-0.5 \mathrm{~cm}$ for stem diameter. These results are within the range of the results obtained by Stamets and Chilton (1983); Oei (1991) and Zhanxi and Zhanhua (2001).

\subsection{Chemical component and nutritive value}

Fruit bodies of F.velutipes grown on different media were chemically analyzed for their content of moisture, crude protein, crude fiber, ash and total carbohydrates. Moisture content of mushroom fruit bodies represents the major component in their chemical composition. The chemical component and nutritive value were affected by different substrates, (Table 4).

\subsubsection{Moisture percentage}

There were significant differences in moisture (\%) between mushrooms cultivated in different substrates. Sawdust substrate caused the highest content of moisture percentage, while faba bean stalks resulted in the lowest values in both seasons. The present results are in good agreement with the range of the data obtained by Crisan and Sands (1978), and Yuexin (1999). They found that $F$. velutipes fruit bodies contained( $88.7-92 \%)$ moisture. Sheng et al. (1997)stated that moisture content was recorded (82-89\%) when $F$. velutipes were cultivated on rice straw, sawdust, corn cobs and cotton seed husk.

\subsubsection{Crude protein percentage}

Flammulina mushroom grown on faba bean stalks recorded the highest crude protein percentage followed by wheat straw, white maize cobs followed by sawdust substrates resulted in the lowest values in both seasons. Many authors, found that the protein content of $F$. velutipes was 20.11-33.20\% (Crisan and Sands, 1978, Fujihara et al., 1995and Zhanxi and Zhanhua, 2001).

\subsubsection{Fiber percentage}

cultivated in sawdust or faba bean stalks substrates had the highest fiber percentage content in the first and the second seasons, respectively. On the other hand, Flammulina velutipes grown in wheat straw recorded the lowest values in both seasons.Also, Crisan and Sands ( 1978) recorded that $F$. velutipes fruit bodies contained $3.7 \%$ crude fiber. Similarly, Tonomura (2001) stated that the crude fiber content of $F$. velutipes was $3.3 \%$ on dry weight basis while Kurusawa et al. (1982) recorded $12.2 \%$ crude fiber on dry weight basis . 3.5.4. Ash percentage
There were significant differences between ash percentage content of Flammulina mushrooms grown in different substrates (Table 4).

The highest values of ash percentage were obtained from mushrooms cultivated on sawdust followed by rice straw, while it recorded the lowest values when grown in maize cobs substrate in both seasons. Crisan and Sands (1978) mentioned that, $F$. velutipes fruit bodies contained $7.4 \%$ ash (on dry weight basis). Also, Tonomura (2001) stated that the ash content was $7.6 \%$ on dry weight basis. While, $10.2 \%$ was recorded by Yuexin (1999).

\subsubsection{Crude fat percentage}

Crude fat content of Flammulina velutipes was affected significantly by different substrates in the first season, while there was no significance in the second. The highest values were recorded by faba bean stalks followed by rice straw, while the lowest ones caused by maize cobs substrates. Crisan and Sands (1978) mentioned that, lipid contents of $F$. velutipes fruit bodies were $1.9 \%$ (on dry weight basis). Tonomura (2001) recorded $5.8 \%$ fat (on dry weight basis). Meanwhile, Koyama et al. (1984) found that the lipids content of $F$. velutipes was $6.9 \%$ on the dry matter. Meanwhile, Sheng et al. (1997) found that the lipids content ranged between 1.79-2.977\%. On the other hand, higher lipid contents for $F$. velutipes were recorded by Yang et al. (2001) who found that the crude fat was 8.89 and $9.23 \%$ on the dry basis for white and yellow $F$. velutipes in succession.

\subsubsection{Total carbohydrate percentage}

Data presented in Table (4) show significant differences between the effect of substrates on total carbohydrates percentage of Flammulina velutipes in both seasons. Mushrooms grown on maize cobs contained the highest values of total carbohydrates. Crisan and Sands (1978) mentioned that the fruit bodies of $F$. velutipes contained $73.1 \%$ total carbohydrates.

Moreover, Sheng et al. (1997) found that the total carbohydrate content ranged from 43.33$61.21 \%$ according to mushroom strain and cultivation medium. Meanwhile, Yuexin (1999) demonstrated that the total carbohydrates content of $F$. velutipes fruit bodies (on dry weight basis) was $61.22 \%$.

\subsubsection{Chemical component of substrates after and before cultivation:}

From the present data it was observed that there were changes in the chemical components of substrates after cultivation compared to substrates before cultivation. As shown in Tables (5 and 6) data indicate that there were significant differences between different substrates before 
and after cultivation in both seasons. except in crude fat percentage in the second season which
(1993), Aly (1994), Mohammady (1996), Khaled (1997) and Hassan (2002) who found that nitrogen

Table (4): Effects of substrates on the chemical components: protein, ash, fiber and total carbohydrates of $F$. velutipes

\begin{tabular}{|c|c|c|c|c|c|c|}
\hline \multicolumn{7}{|c|}{ First season $(2007-2008)$} \\
\hline $\begin{array}{l}\text { Component \% } \\
\text { Substrates }\end{array}$ & Moisture & Protein & Fibers & Ash & Fats & T. carbohydrates \\
\hline Rice straw & 87.00 & 21.60 & 9.40 & 7.50 & 2.93 & 58.57 \\
\hline Wheat straw & 88.40 & 23.40 & 7.00 & 7.20 & 2.18 & 60.27 \\
\hline Maize cob & 85.80 & 19.10 & 8.40 & 6.80 & 1.88 & 63.87 \\
\hline F. beans stalks & 84.50 & 24.30 & 12.50 & 7.36 & 3.00 & 52.84 \\
\hline Sawdust & 89.20 & 21.40 & 12.60 & 8.00 & 2.10 & 55.90 \\
\hline LSD 5\% & 2.11 & 2.38 & 0.79 & 0.56 & 0.21 & 6.53 \\
\hline \multicolumn{7}{|c|}{ Second season $(2008-2009)$} \\
\hline $\begin{array}{l}\text { Component \% } \\
\text { Substrates }\end{array}$ & Moisture & Protein & Fibers & Ash & Fats & T. carbohydrates \\
\hline Rice straw & 88.10 & 22.10 & 9.00 & 7.30 & 2.79 & 58.81 \\
\hline Wheat straw & 86.30 & 23.60 & 7.20 & 7.20 & 2.00 & 60.27 \\
\hline Maize cob & 87.20 & 19.30 & 8.10 & 6.50 & 1.71 & 64.39 \\
\hline F. beans stalks & 85.00 & 24.00 & 12.70 & 7.10 & 3.12 & 53.08 \\
\hline Sawdust & 88.90 & 21.90 & 12.30 & 7.90 & 2.00 & 55.90 \\
\hline LSD 5\% & 1.91 & 0.87 & 0.52 & 0.86 & N.S. & 2.34 \\
\hline
\end{tabular}

showed no significant difference. Maize cobs contained the highest values of moisture and total carbohydrate percentage in the substrates before cultivation. These results of moisture content are in agreement with those reported by Stamets and Chiltion (1983), Stamets (1993) and Khaled (1997) who found that the moisture content of some agricultural and industrial wastes included rice straw, wheat straw, bean peels, sawdust and corn stalks ranged from 7.5 to $17.2 \%$. On the other hand, the presented results are higher than those found by Hassan (2002), who stated that rice, wheat, soybean straws and sawdust contained 6.99-9.58\% moisture. Concerning the total carbohydrate, the data in the present study are in agreement with the values obtained by Heltay and Zavodi (1960), Gramss (1979) and Hassan (2002). They found that, the total carbohydrate of some wastes ranged from 48.8 to $55.88 \%$. While after cultivation sawdust and rice straw substrates had the highest values of moisture percentage in the first and the second seasons, respectively. On the other hand, maize cobs and rice straw substrates contained the highest values of the total carbohydrate percentage in the first and second seasons, respectively. Faba bean stalks contained the highest values of crude protein in both cases after and before cultivation. These results are in accordance or nearly similar to those obtained by Kaul et al. (1981), Mehta et al. (1990), Stamets content of faba been stalks ranged from 0.9$1.14 \%$. After and before cultivation sawdust had the highest values of fibers while wheat straw had the highest values of ash and fats. Concerning ash, the present results of ash content of sawdust are in accordance with that obtained by Mohammady (1996)3.02\%. Before cultivation sawdust had the lowest values of moisture,crude protein, ash, crude fats and total carbohydrates percentage. While wheat straw contained the lowest values of fibers in both seasons. On the other hand, after cultivation sawdust substrates had the lowest values of crude protein, ash, fats and total carbohydrates in both seasons. Meanwhile, faba bean stalk substrate had the lowest moisture percentage in both seasons. Rice straw had the lowest values of fiber percentage after cultivation, in both seasons.

From the aforementioned results in the present study it could be concluded that:

1- Cultivation of $F$. velutipes mushrooms that are newly introduced to Egypt from China under the local environmental conditions on cheap lignocellulosic wastes is a very important achievement. Since, F. velutipes mushroom is highly prized for its nutritive and medical benefits.

2- In wastes, crude protein and ash increased. While fibers, fats and total carbohydrates percentage decreased after cultivation. 
Table (5): Chemical component of substrates before cultivation.

\begin{tabular}{|c|c|c|c|c|c|c|}
\hline \multicolumn{7}{|c|}{ First season (2007-2008) } \\
\hline $\begin{array}{l}\text { Component \% } \\
\text { Substrates }\end{array}$ & Moisture & Protein & Fibers & Ash & Fats & T. carbohydrates \\
\hline Rice straw & 8.50 & 4.60 & 30.80 & 14.10 & 2.10 & 48.40 \\
\hline Wheat straw & 7.50 & 4.90 & 28.50 & $\mathbf{1 7 . 3 0}$ & 2.60 & 46.70 \\
\hline Maize cob & 11.20 & 4.40 & 33.10 & 10.60 & 1.50 & 50.40 \\
\hline F. bean stalks & 9.40 & 8.80 & 39.00 & 11.10 & 1.40 & 39.70 \\
\hline Sawdust & 5.80 & 2.50 & 62.20 & 7.50 & 0.90 & 26.90 \\
\hline LSD 5\% & 0.51 & 0.74 & 7.91 & 4.40 & 0.45 & 1.66 \\
\hline \multicolumn{7}{|c|}{ Second season $(2008-2009)$} \\
\hline $\begin{array}{l}\text { Component \% } \\
\text { Substrates }\end{array}$ & Moisture & Protein & Fibers & Ash & Fats & T. carbohydrates \\
\hline Rice straw & 8.30 & 4.10 & 34.10 & 13.90 & 2.10 & 45.80 \\
\hline Wheat straw & 7.10 & 4.80 & 30.90 & 16.80 & 2.40 & 45.10 \\
\hline Maize cob & 11.30 & 4.20 & 34.40 & 11.30 & 1.60 & 48.50 \\
\hline F. bean stalks & 9.20 & 8.10 & 38.80 & 10.70 & 1.40 & 41.00 \\
\hline Sawdust & 5.30 & 2.20 & 58.00 & 6.80 & 1.10 & 31.90 \\
\hline LSD $5 \%$ & 0.87 & 0.55 & 6.35 & 1.31 & 0.35 & 6.41 \\
\hline
\end{tabular}

Table(6): Chemical component of substrates after cultivation $F$. velutipes.

\begin{tabular}{|c|c|c|c|c|c|c|}
\hline \multicolumn{7}{|c|}{ First season (2007-2008) } \\
\hline $\begin{array}{l}\text { Component\% } \\
\text { Substrates }\end{array}$ & Moisture & Protein & Fibers & Ash & Fats & T. carbohydrates \\
\hline Rice straw & 73.10 & 9.40 & 25.70 & 32.50 & 1.30 & 31.10 \\
\hline Wheat straw & 67.90 & 10.60 & 33.60 & 37.10 & 1.30 & 27.40 \\
\hline Maize cob & 66.90 & 7.20 & 28.50 & 30.50 & 0.80 & 33.00 \\
\hline F. bean stalks & 65.00 & 12.10 & 33.50 & $\mathbf{3 0 . 5 0}$ & 1.00 & 22.50 \\
\hline Sawdust & 74.20 & 5.90 & 49.80 & 27.50 & 0.50 & 16.30 \\
\hline LSD 5\% & 1.58 & 0.38 & 5.44 & 2.43 & 0.23 & 3.02 \\
\hline \multicolumn{7}{|c|}{ Second season (2008-2009) } \\
\hline $\begin{array}{l}\text { Component\% } \\
\text { Substrates }\end{array}$ & Moisture & Protein & Fibers & Ash & Fats & T. carbohydrates \\
\hline Rice straw & 74.20 & 9.20 & 23.10 & 31.10 & 1.20 & 35.40 \\
\hline Wheat straw & 68.40 & 10.10 & 35.20 & 35.20 & 1.40 & 28.10 \\
\hline Maize cob & 67.10 & 7.00 & 27.80 & 30.90 & 0.80 & 33.50 \\
\hline F. bean stalks & 66.20 & 11.90 & 34.30 & 32.10 & 1.00 & 20.70 \\
\hline Sawdust & 73.10 & 5.20 & 47.60 & 26.90 & 0.60 & 19.80 \\
\hline LSD 5\% & 2.22 & 0.99 & 2.59 & 3.55 & N. S. & 2.48 \\
\hline
\end{tabular}

\section{REFERENCES}

A. O. A. C. (1980). Official Methods of Analysis of the Association of Analytical Chemists, $14^{\text {th }}$ ed, Washington, D.C.,U.S.A.

Aly A.Z.M. (1994). Biochemical Studies on the Utilization of Agricultural Wastes for Growing Some Mushroom Species. Ph.D. Thesis, Fac. of Agric., Cairo Univ.233pp.

Bahl N. (1994). "Handbook on Mushrooms" $3^{\text {rd }}$ ed. Published by Oxford \&IBH Publishing Co. PVT. LTD, New Delhi, India.

Chang S. T. and Quimio T.H. (1982). Tropical Mushrooms. Biological Nature and culture Method. The Chinese Univ. Press. Hong Kong.
Crisan E. and Sands A. (1978). Nutritional value in "Biology and Cultivation of Edible Mushrooms"Editors: S.T. Change and W. A. Hayes. p. 137-187. Publishing by Academic Press Inc. U.S.A.

Flegg P. (1997). Micro-organisms in the substrate. The Mushroom Journal, 566: 24-25.

Fujihara S., Kasuga. M., Aoyagi Y. and Sugahara T. (1995). Nitrogen to protein conversion factors for some common edible mushroom. Journal of Food Science, 60(5) 1045-1047.

Ghada M. M. (2004). Production and Processing of Flammulina velutipes and Lentinus edodes. P h. D. Thesis, Fac. of Agric., Cairo Univ.240pp. 
Gomez K. A and Gomez A. A (1984). Statistical Records for Agric. Res. 2 ${ }^{\text {nd }}$. Ed. John Wiley\&Sons. Bup. p. 139-153.

Gramss G. (1979). Some differences in response to competitive microorganisms deciding on growing success and yield destroying edible fungi. Mushroom Science, 10 (1): 265-285.

Hassan F. R. H (2002). Studies on Bioconversion of Some Agricultural Wastes Using Pleurotus and Agarcus mushrooms. Ph. D. Thesis, Fac. of Agric, Cairo Univ., Egypt.189 pp.

Heltay I. and Zavodi I. (1960). Rice straw compost. Mushroom Sci., 4:393-399.

Hong J., Wang, H., Hui Z. O., Hong H., Wei J. and Zhang W. (2001). Preliminary researches on Flammulina velutipes, and Ganoderma lucidum cultivation using maize straw. Edible Fungi of China, 20 (6): 11-12.

Kaul T., Khurana M. and Kchroo J. (1981). Chemical composition of cereal straw of the Kashmir Valley. Mushroom Sci.,11 (2): 1925.

Khaled A. M. (1997). Studies on the Production and Evaluation of Oyster Mushroom. Ph. D. Thesis. Fac. of Agric. Cairo. Univ. 212p.

Koyama N., Aoyagi Y. and Sughara T. (1984). Fatty acids composition and ergoostrol contents of edible mushrooms . J . Jap. Soc. Food Sci. Technol.31:732-738.

Kurtzman R.H.(1974). The metabolism of fatty substances by the oyster mushroom. Proc. of the $9^{\text {th }}$ International Scientific Congress on the Cultivation of Edible Fungi .Tokyo; 557-565.

Kurusawa S., Sugahara T. and Hayashi J. (1982). Studies on dietary fiber on mushrooms and edible wild plants., Nutr. Rep. Inc., 26: 167173.

Leong P. C. (1980). Utilization of cotton waste substrate with treatment for the cultivation of Oyster mushroom. (Pleurotus). In Singapore. Journal of Primary Industries 8 (1): 21-27. (c. a. Hort. Abst. 51, 8, 6295, 1981).

Lu Q. G., Gui Y. M. and Tong X. L. (1989). Mycelium growth and mushroom yield of Flammulina velutipes on different culture media. Jiangsu Agricultural Sciences., (3): 26-27.

Madbouly F. H. (1987). Some Studies on Cultivation and Preservation of Mushrooms. Ph. D. Thesis, Fac. of Agric., Cairo Univ. 205pp.

Madbouly F. H., Farrag A. M. and Khereba A. H. (1993). Chemical constituents of mushroom (Pleurotus spp.) as affected by substrate, strains and their interaction. Fifth Arab Conf. of Food Sci. \&Tec. 583-601 .

Mehta V., Gupata J. K. and Kaushal S. C. (1990). Cultivation of Pleurotus mushroom on rice straw and biogas. Production from spent straw. World Journal of Microbiology and Biotechnology, (6): 36-370.

Mohammady T. F. (1996). Utilization of Organic Wastes for Cultivation and Production of Mushroom. Ph. D. Thesis, Faculty of Agriculture, Ain Shams Univ.245pp.

Nanagulyan S. G. (2000). Applied researches on edible mushrooms in the republic of Armenia Proceeding the $15^{\text {th }}$ International Congress on. Science and Cultivation of Edible Fungi, Edited by L. J. L. D- Van Griensven, 15-19 May, Maastricht/ Netherlands, Volume II: p. 783-787.

Oei P. (1991). "Manual on Mushroom Cultivation" First Published by Tool Publication. Amesterdam, The Netherland. , Volume II: pp. 511-604.

Pawalk R., Siwulski M., Kosson R., Szwe J. J. and Gorecka K. (2001). The effect of different cultivation media on the yield of Flammulina velutipes (Curtis: Fries) singer. Biological and agrotechnical aspects of vegetable crops manangement. Proceedings of National Polish Vegetable Crops Conference, Skierniewic, Poland, 21-22 June 2001. Vegetable Crops Research Bulletin. 2001, 54 (2): 93-96.

Royse D. J. (1995). Specially mushrooms cultivation on synthetic substrate in the USA and Japan. Mushroom News, May, 419.

Sharma V.P.S.R and Satish K. (2006). On the productivity of Flammulina velutipes. India, Mushroom Research. (2006). 15:2, 129-134.

Sheng J. W., Jia S. M., Wu J. J. and Jia J. H. (1997). Nutritional composition of Flammulina velutipes. Edible-fungi-of China.; 16 (5): 36-38.

Singh M. P. (2000). Biodegradation of lignocelluslosic wastes through cultivation of Pleurotus Sajor-caju. Proceeding the $15^{\text {th }}$ International Congress on Science and Cultivation of the Edible Fungi, Editions by L. J. L-D. Van Griensven, 15-19 May, Masstricht/ Netherland, Volume II p. 517521.

Stamets P. (1993). "Growing Gourmet and Medicinal Mushrooms" Published by, Ten Speed Press, Berkeley, CA 94707.

Stamets P. and Chiltion J. S. (1983). "The Mushroom Cultivar": A Practical Guide to 
Growing Mushrooms at Home. Agaricon Press, Olympia, Washington.

Tange Z. N., Bian G. Q., Zhang M., Yang H. B and Yu J. H. (2001). Studies on cultivating Flammulina velutipes (Fr) Sing with paspalue Notatum flugge Edible Fungi of China 20 (4): 10-12.

Tonomura (2001). Flammulina velutipes in "The Biology and Cultivation of Edible Mushrooms" Editors.: S. T. Change and W. A. Hayes. 410-420 pp. Publisheing by Academic Press. Inc. U. S. A.

Vangriensven. L. J. L. D. (1988). The Cultivation of Mushrooms, $1^{\text {st }}$ (ed). published in co-operation with and sponsored by Darlington Mushroom Laboratories LTD, Rustington, Sussex, England.

Venkatroman K., Kisha S. and Gupta B. N. (1989). Changes in composition of straw on treatment with Callybia Velutipes and Coprinus fietoriusm. Indian Journal of Animal Nutrition, 6 (4): 307- 316.

Xiong H. and Jiang X. J. (1999). Studies on culture of Flammulina velutipes with quail ordure. Research of Agricultural Modernization. 20, (2): 125-127.

Yamanaka K. (1997). Production of cultivated edible mushrooms. Food Reviews International, 13(3): 327-333.

Yang X. B., Xiong W. P. and Chamba C. (2001). Comparative trials on six Flammulina velutipes strains introduced to Tibet. Edible Fungi of China. 20 (2): 11-12.

Yuexin L. (1999). Instant notes in edible fungi. International training class Jun-Cao Technology Institute, Fujian Agricultural Univ. China.

Zhang D .J., Jun W.Q., Dang, J.Z., Ge G. and Wu Q .J.(2001). Studies on row material culture and physiology of white Flammulina velutipes.Chinese Research of Agricultural modernization .22(5):230-241.

Zhanxi L. and Zhanhua L. (2001). The Textbook for International Training Class, Jun-Cao, Fujian Agricultural Univ. China.

Zou X.Y., Zhao H. B., Qiao D. and Li S. M. (2005). Optimization of the combinations of growth-promoting agents for Flammulina velutipes. China; Plant Protection, 31(5):3 48-352. 3 ref.

\section{تأثير بعض المخلفات الزراعية على نمو وانتاج و القيمة الغذائية

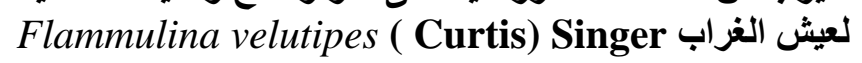

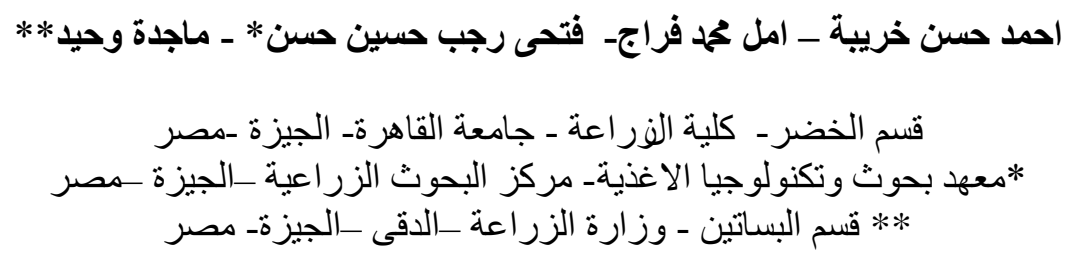

